\title{
Meat and carcass traits of the red-winged tinamou (Rhynchotus rufescens)
}

\section{-Author(s)}

Queiroz FA de

Carvalho $\mathrm{MM}^{\mathrm{de}} \mathrm{e}^{2}$

Sugui JK ${ }^{1}$

Nunes $J^{1}$

Felipe $L^{1}$

Santos EC dos

Tonhati $\mathrm{H}^{1}$

Boiago $\mathrm{MM}^{3}$

Hata $\mathrm{ME}^{1}$

Tholon P4

Queiroz SA de

Departamento de Zootecnia - Faculdade de Ciências Agrárias e Veterinárias Campus de Jaboticabal, UNESP. Via de acesso Prof. Paulo Castelane $\mathrm{s} / \mathrm{n}^{\circ}$, Jaboticabal, 14884 900, São Paulo, Brazil. CNPq fellowship

2 Divisão de Licenciamento e Controle Ambiental - Secretaria do Meio Ambiente - Rua Ipitá, 193, Jardim Inamar, Diadema, 09970-350, São Paulo, Brazil.

3 Departamento de Zootecnia - Centro de Educação Superior do Oeste - Universidade do Estado de Santa Catarina, UDESC. Rua Benjamin Constant, 84E, Chapecó , 89.802-200, Santa Catarina, Brazil.

4 Embrapa CPPSE - Rodovia Washington Luiz, km 234 - CEP 13560-970 - São Carlos, São Paulo, Brazil.n

\section{Mail Adress}

Corresponding author e-mail address Sandra Aidar de Queiroz. Departamento de Zootecnia - Faculdade de Ciências Agrárias e Veterinárias Campus de Jaboticabal, UNESP. Via de acesso Prof. Paulo Castelane $s / n^{\circ}$, Jaboticabal, 14884900, São Paulo, Brazil. Phone: 5516 32092678. E-mail: saquei@fcav.unesp.br

\section{nKeywords}

Carcass yield, lightness, pH, shear force, water holding capacity.

\section{ABSTRACT}

Tinamou (Rhynchotus rufescens) is a native bird of the Brazilian fauna and has great potential to become a domesticated species. From this perspective, the objective of this study was to evaluate the carcass and main parts yield and to assess meat quality of that bird. Two trials, one studying stocking density and the other litter materials, lasting 60 days each, were conducted. The studied traits were evaluated in two birds/ replicate/treatment. Performance was evaluated by the least square method. The results showed that bird age at slaughter significantly influenced carcass and breast yields $(p<0.05)$. Mean carcass, breast, thighs+drumstick and wing yields were $86.50 \pm 2.78 \%, 32.84 \pm 1.50 \%$, $27.71 \pm 1.44 \%$, and $13.21 \pm 0.94 \%$, respectively. Shear force, $\mathrm{pH}$, water holding capacity, lightness, redness and yellowness means and standard deviations were $1.92 \pm 0.98 \mathrm{kgf} . \mathrm{cm}^{-2}, 6.07 \pm 0.12 ; 70 \pm 0.53 \%$, $48.30 \pm 0.96,1.96 \pm 1.01$, and $1.61 \pm 1.0$, respectively. Moisture, ash, crude protein, fat, and cholesterol contents were $72.35 \pm 0.16 \%$, $1.12 \pm 0.06 \%, 25.53 \pm 0.50 \%, 0.17 \pm 0.01 \%$, and $18.87 \pm 2.76 \mathrm{mg} / 10 \mathrm{~g}$, respectively. Results showed carcass and parts yields and the physicalchemical traits of tinamou meat are similar to chicken meat; however, tinamou meat is less acidic and has higher protein level combined with less calories and lower cholesterol levels.

\section{INTRODUCTION}

The red-winged tinamou (Rhynchotus rufescens) is a native bird of the Brazilian fauna and can be found in rural areas, savannahs, and open uplands. It is the largest bird among the rural species of the Tinamiformes order. It is a ground bird, similar in appearance to the European partridge (Perdix sp. and Alectoris sp.). Its reproductive season lasts from September to March and it is characterized by the fact that the males incubate the eggs until hatching and are responsible for chick care (Sick, 1997). It was traditionally the favourite bird for sport hunting in Brazil due to its short and low flight, and because it inhabits fields with low vegetation, allowing the use of hunting dogs and good shooting conditions. Over the years, there have been some initiatives to breed the tinamou for commercial and preservation purposes, since population numbers are declining due to extensive occupation of the savannahs by cattle herds and the Brazilian taste for their meat.

In studies performed with tinamou bred in captivity in conditions similar to commercial poultry, the birds reached mature weight that varied from 710 to $1000 \mathrm{~g}$ (Weeks, 1973; Bruneli et 
al., 2005 and Queiroz \& Cooper, 2011). Tholon \& Queiroz (2007), studying tinamou performance, reported that average mature weight ranged between $686.0 \pm 2.52 \mathrm{~g}$ and $647.0 \pm 3.07 \mathrm{~g}$, for females and males, respectively, suggesting little sexual dimorphism of this trait. The adult female is heavier than the male possibly because it needs more body capacity to carry the eggs (Queiroz \& Cooper, 2011).

Tinamou is sought for its meat and high hunting value due to a growing demand for exotic meats (Gaya \& Ferraz, 2006), in addition to being an excellent alternative source of animal protein, with high carcass and breast yields. However, little information is available about the quality and characteristics of its meat. In order to increase the scientific knowledge on the species, this study aimed at evaluating carcass and parts yields, as well as meat physicalchemical characteristics of red-wing tinamous.

\section{MATERIAL AND METHODS}

The study was conducted at Setor de Animais Silvestres (Wildlife Division), Faculdade de Ciências Agrárias e Veterinárias, UNESP, Jaboticabal, SP, Brazil. Two trials were carried out: from December, 2008 to February, 2009 (Trial 1) and from July to September, 2009 (Trial 2). A number of 51 male and female tinamous, between 150 and 250 days of age was evaluated. Birds were housed in a masonry poultry house divided into $2.50 \times 1.45 \times 2.00 \mathrm{~m}$ pens separated by wire screen and covered with coast cross hay (Cynodon dactilum) litter. Birds were submitted to the same management practices used in commercial poultry farms, with ad libitum access to feed (28\% crude protein and 2800 $\mathrm{kcal}$ metabolizable energy/kg) and water.

Trial 1 was designed to evaluate different stocking densities $\left(7.5\right.$ birds $/ \mathrm{m}^{2}, 5$ birds $/ \mathrm{m}^{2}, 2.5 \mathrm{birds} / \mathrm{m}^{2}$, or 2.0 birds $/ \mathrm{m}^{2}$, with four replicates each). Birds were distributed in 16 pens, according to age and weight, so that each treatment included birds of all ages. In Trial 2, different types of litter were studied (grass hay, rice husks, peanut hulls, sand, and wood shavings, with four replicates each). Birds were distributed in 20 pens, with eight birds each. Two birds from each replicate were randomly chosen for sacrifice. Birds of all age classes were present in each treatment, according to the following classes: class $1=110$ to 150 days; class $2=151$ to 200 days and class $3=201$ to 205 days. Both trials lasted 60 days.
Before sacrifice, breast length and large and small width were measured in all birds using a pachymeter, according to the diagram shown in Figure 1. Breasts were graded according to the following scores: $0=$ meagre, $1=$ narrow, $2=$ medium and $3=$ full (Figure 1 ).

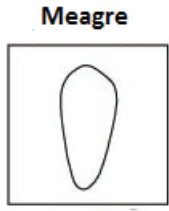

Score 0

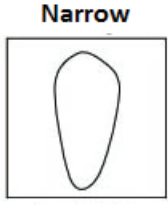

Score 1

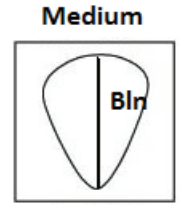

Score 2

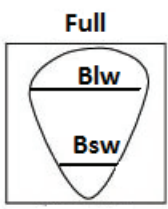

Score 3
Figure 1 - Diagram of tinamou (Rhynchotus rufescens) breast showing scores from 0 to 3 and measurement of breast length (Bln), large width (Blw) and small width (Bsw).

Birds were then wing banded, weighed, and slaughtered after a 12-hour feed withdrawal. Slaughter was performed according to commercial plant procedures, that is, birds were stunned in a water bath with electric current, bled, boiled for 3 minutes at $54{ }^{\circ} \mathrm{C}$, plucked, and eviscerated. Carcasses were then pre-chilled in tanks with water at $18^{\circ} \mathrm{C}$ for 15 minutes, and subsequently chilled in tanks with water and ice at $2^{\circ} \mathrm{C}$ for 30 minutes. After dripping, cold carcasses and parts (breast, legs, back, feet and neck) were weighed. Breasts were deboned, wrapped in polyethylene bags and refrigerated until analysis. Hot carcass weight was determined immediately after the first chilling step $\left(18^{\circ} \mathrm{C}\right.$ for 15 minutes).

Parts and carcass yields were calculated by dividing parts weights by cold carcass weight, and hot carcass weight by live weight at slaughter, respectively. Weight loss during fasting was determined by subtracting pre-fasting weight from slaughter weight; water absorption in the chiller was calculated as cold minus hot carcass weight.

After rigor mortis was established (6 hours after slaughtering), an electrode was introduced directly into the breast muscle (Pectoralis major) to determine $\mathrm{pH}$ using a Texto $\mathrm{pHmeter}$.

Shear force was determined using a Texture Analyzer TA-XT 2/i coupled to a Warner-Bratzler blade. Breast meat samples (Pectoralis major) were placed in polyethylene bags, immersed in water bath $\left(85^{\circ} \mathrm{C}\right)$ for 30 minutes, cooled to room temperature, and cut into strips measuring approximately $1.5 \times 1.5 \mathrm{~cm}$. Meat fibers were placed perpendicular to the blade unit, which promoted the strength $\left(\mathrm{kgf} / \mathrm{cm}^{2}\right)$ required to shear the sample (Lyon et al., 1998). 
Water holding capacity was determined according to methodology described by Hamn (1960) in approximately $2.0 \mathrm{~g}$ of deboned breast sample. Samples were placed between two filter papers and plexiglass plates, where a $10 \mathrm{~kg}$-weight exerted pressure during 5 minutes. After that, the meat was weighed to determine water holding capacity (Whc), expressed as percentage.

Color measurements were performed on the inside of the muscle Pectoralis major using a spectrocolorimeter Minolta Chroma Meter CR-300, with the system CIELAB ( $L^{*}, a^{*}$ and $\left.b^{*}\right)$. The latter describes opponentcolor scales based on the theory of opponent-color of human color vision. The $a^{*}$ value indicates redness when positive, or greenness when negative. The value $b$ * (yellowness) indicates yellowness when positive, or blueness when negative. Lightness $\left(L^{*}\right)$ describes the relationship between absorbed and reflected light, where 100 is white and 0 is black.

In order to determine moisture content, a previously deboned and ground breast meat sample was weighed and subsequently placed to a forced-ventilation oven at $60^{\circ} \mathrm{C}$ for 72 hours. Dry matter was determined after the sample was left to cool and weighed again. Ashes were determined from this same sample following standard procedures.

Protein and cholesterol levels were determined according to AOAC (2004) and Bragnolo \& RodriguesAmaya (1993), respectively.

\section{Statistical analysis and models}

Carcass yields (Cy), breast yield (By), drumstick and thigh yields (Dty), wing yield (Wy), fasting losses (FI) and water absorption in the chiller (Wac) were analyzed by the least square method of the GLM procedure (SAS 9.1, SAS Institute, Cary, North Carolina, USA) and the test of Tukey was applied to compare means ( $P=0.05)$. The statistical model used in the analysis was:

$Y_{i j k m}=\mu+T_{i}+A_{j: i}+b\left(x_{k}-x\right)+S_{1}+e_{i j k l m ;}$ where :

$\mathrm{Y}_{\mathrm{ijkl}}=$ studied trait;

$\mu=$ mean;

$T_{i}=$ effect of the $i^{\text {th }}$ trial $(i=1 ; 2)$;

$A_{\mathrm{j}: \mathrm{i}}=$ effect of the $j^{\text {th }}$ treatment within the $i^{\text {th }}$ trial $(j=1 ; \ldots 8)$;

$b=$ linear regression coefficient;

$x_{k}=$ effect of the $k^{\text {th }}$ age class $(k=1,2$ and 3$)$;

$\mathrm{x}=$ bird average age;

$S_{1}=$ effect of the $\left.\right|^{\text {th }}$ sex $(1=$ female and $2=$ male); $\mathrm{e}_{\mathrm{ijk} \mathrm{m}}=$ random error assumed to be normal and independently distributed $\left(0, \sigma_{\mathrm{e}}^{2}\right)$.

Shear force (Sf), $\mathrm{pH}$, water holding capacity (Whc), lightness $\left(L^{*}\right)$, redness $\left(a^{*}\right)$ and yellowness $\left(b^{*}\right)$ were submitted to analysis of variance by the least square method and Tukey's test was used to compare the means ( $p=0.05$ ). This analysis used data generated in the stocking density trial (trial 1). The statistical model used was:

$Y_{i j k \text { mnop }}=\mu+T_{i}+E_{j}+S_{k}+l_{1}+b_{1}\left(x_{m}-x\right)+b_{2}\left(y_{n}-y\right)+$ $b_{3}\left(z_{0}-z\right)+b_{4}\left(v_{p}-v\right)+e_{i j k l m n o p q ;}$ where:

$Y_{i j k l m n o p}=$ studied trait;

$\mu=$ mean;

$T_{i}=$ effect of $i^{\text {th }}$ treatment $\left({ }_{i}=1 ; 2 ; 3 ; 4\right)$

$E_{i}=$ effect of $j$ th breast score $(j=2 ; 3$ and 4$)$;

$\mathrm{S}_{\mathrm{k}}=$ effect of $\mathrm{k}^{\text {th }}$ bird sex ( $1=$ female e $2=$ male);

$I_{1}=$ effect of It $^{\text {th }}$ age class $\left({ }_{\mathrm{j}}=1 ; 2 ; 3 ;\right)$

$b_{1}, b_{2}, b_{3}$ and $b_{4}=$ linear regression coefficient;

$\mathrm{x}_{\mathrm{m}}=$ effect of $\mathrm{m}^{\text {th }}$ breast weight;

$\mathrm{x}=$ mean weight of bird breast;

$\mathrm{y}_{\mathrm{n}}=$ effect of $\mathrm{n}^{\text {th }}$ breast length $(\mathrm{cm})$;

$\mathrm{y}=$ mean length of breast $(\mathrm{cm})$;

$\mathrm{z}_{\mathrm{o}}=$ effect of $\mathrm{O}^{\text {th }}$ breast large width $(\mathrm{cm})$;

$\mathrm{z}=$ mean of large breast width $(\mathrm{cm})$;

$v_{p}=$ effect of $p^{\text {th }}$ small breast width $(\mathrm{cm})$;

$\mathrm{v}=$ mean of small breast width $(\mathrm{cm})$;

$\mathrm{e}_{\mathrm{ijklmnopq}}=$ random error assumed normal and independently distributed $\left(0, \sigma_{\mathrm{e}}{ }^{2}\right)$.

Moisture, ashes, crude protein, fat and cholesterol levels were analyzed using 10 birds from trial 2. Means and standard deviations were calculated for these traits.

\section{RESULTS AND DISCUSSION}

Average live pre-slaughter and slaughter weights were, respectively, $720.44 \pm 67.62$ and $688.56 \pm 63.68 \mathrm{~g}$, and average weight loss after fasting was $31.87 \pm 8.74$ g (Table 1). Queiroz \& Cooper (2011) reported values of $786.60 \pm 79.91$ and $747.20 \pm 59.35 \mathrm{~g}$ live weight for adult female and male tinamous, respectively. The average slaughter weight of tinamous at 56 weeks of age was estimated as $637.30 \mathrm{~g}$ by Moro et al. (2006).

Carcass water absorption in the chiller was $25.62 \pm 10.26 \mathrm{~g}$, and therefore, cold carcass weight (Ccw) was slightly higher compared to the hot carcass weight $(\mathrm{Hcw})$, corresponding to $605.93 \pm 60.81 \mathrm{~g}$ and $590.31 \pm 61.44 \mathrm{~g}$, respectively (Table 1 ). 
Table 1 - Number of observations (N), mean (M) and standard deviation (SD) of weight loss after fasting (WIf), hot carcass weight $(\mathrm{Hcw})$, cold carcass weight $(\mathrm{Ccw})$, water absorption in the chiller (Wac), breast weight (Bw), breast length $(B \mid n)$, breast large width (Blw), breast small width (Bsw) and tinamou (Rhynchotus rufescens) breast score (Es)

\begin{tabular}{ccccccccccc}
\hline & N & Wlf g & How g & Ccw g & Wac g & Bw g & Bln cm & Blw cm & Bsw cm & Es \\
\hline M & 32 & 31.87 & 590.31 & 605.93 & 25.62 & 204.56 & 10.82 & 5.33 & 3.10 & 2.84 \\
SD & 32 & 8.74 & 61.44 & 60.81 & 10.26 & 21.78 & 0.53 & 0.55 & 0.31 & 0.32 \\
\hline
\end{tabular}

Breast weight (Bw) was 204.56 $\pm 21.78 \mathrm{~g}$, which was slightly higher than the value observed by Moro et al. (2006), of $173.80 \mathrm{~g}$. Breast measurements, including length (Bln), large (Blw) and small (Bsw) width, as well as breast score (Es), presented small standard deviations (Table 1), and hence could be used to describe tinamou breast shape. It must be noted that the breast score of the studied group varied between 2 and 3 .

Carcass and parts yields were not significantly influenced by trial, treatment, or sex (Table 2). However, this is a pioneering study, and mean values obtained for the species according to sex and trial are presented in Table 3.

Table 2 - Summary of the analysis of variance of carcass (Cy), drumstick and thigh (Dty), breast (By) and wing (Wy) yields of tinamous (Rhynchotus rufescens).

\begin{tabular}{cccccc}
\hline Source of variation & \multicolumn{5}{c}{ Mean square } \\
\hline & DF & Cy & Dty & By & Wy \\
\hline Trial & 1 & 8.86 & 36.98 & 10.54 & 1.35 \\
\hline Treatm. (trial) & 7 & 9.15 & 1.48 & 2.73 & 0.64 \\
\hline Sex & 1 & 0.77 & 1.26 & 0.21 & 1.12 \\
\hline Age & 1 & $29.32^{\star}$ & 0.02 & $29.28^{*}$ & 1.94 \\
\hline Residue & 40 & 7.01 & 1.70 & 2.46 & 0.74 \\
\hline $\mathrm{R}^{2}(\%)$ & & 33 & 56 & 45 & 19 \\
\hline $\mathrm{CV}(\%)$ & & 3 & 5 & 5 & 6 \\
\hline
\end{tabular}

${ }^{*} \mathrm{p}<0.05, \mathrm{CV}=$ coefficient of variation, $\mathrm{R}^{2}=$ coefficient of determination.

Table 3 - Mean carcass (Cy), drumstick+thigh (Dty), breast (By) and wing (Wy) yields of tinamous (Rhynchotus rufescens) according to trial and sex.

\begin{tabular}{lccccc}
\hline Trial & $\mathrm{N}$ & Cy \% & Dty \% & By \% & Wy \% \\
\hline 1 (density) & 26 & $85.48^{\mathrm{a}}$ & $27.15^{\mathrm{a}}$ & $33.72^{\mathrm{a}}$ & $13.14^{\mathrm{a}}$ \\
2 (litter) & 25 & $87.55^{\mathrm{a}}$ & $24.72^{\mathrm{a}}$ & $32.04^{\mathrm{a}}$ & $13.41^{\mathrm{a}}$ \\
\hline Sex & & & & & \\
\hline Female & 31 & $87.18^{\mathrm{a}}$ & $25.23^{\mathrm{a}}$ & $32.26^{\mathrm{a}}$ & $13.33^{\mathrm{a}}$ \\
Male & 20 & $85.44^{\mathrm{a}}$ & $27.07^{\mathrm{a}}$ & $33.87^{\mathrm{a}}$ & $13.44^{\mathrm{a}}$ \\
\hline General & 51 & 86.50 & 32.84 & 24.71 & 13.21 \\
Deviation & 51 & 2.78 & 1.50 & 1.44 & 0.94 \\
\hline
\end{tabular}

a same letter in the column means no significant difference by Tukey test $(p<0.05)$

Expressive average carcass, breast, leg and wing yields were obtained in this study $(86.50 \pm 2.78 \%$, $32.84 \pm 1.50 \%, 27.71 \pm 1.44 \%$ and $13.21 \pm 0.94 \%$, respectively; Table 3$)$. The obtained carcass and wing yield values were higher than those reported for broilers by Denadai et al. (2002) and Oba et al. (2007). Cancherini et al. (2008), working with broilers, reported breast and leg yields similar to values reported by the latter. However, it must be noted that tinamous are in the process of domestication, and have not been submitted yet to any artificial selection process relative to carcass quantitative traits. Therefore, the results obtained are representative of the good production potential of this species.

Moro et al. (2006) reported lower carcass yield (74.4\%) and higher breast yield (36.6\%), for the same tinamou species (Rhynchotus rufescens). Aggrey et al. (1992), working with Nothoprocta perdicaria, a Chilean tinamidae, obtained a carcass yield of $76.8 \%$ for 16 -week-old birds. Kermode (1997) reported $77 \%$ carcass yield for the tinamidae Nothoprocta perdicaria.

Only bird age at slaughter $(p<0.05)$ significantly influenced the evaluated traits, as shown in Table 2. Bird age was significantly and positively correlated with breast and carcass yields $(p<0.05)$, which both increased with bird age also increased due to the increasing meat/bone ratio as birds approach maturity. The change from one age class to the next corresponded to $0.0149 \pm 0.0073 \%$ and $0.0139 \pm 0.0043 \%(p<0.05)$ increments in carcass and breast yields, respectively.

The main meat quality traits sought by consumers are tenderness, color, and juiciness. Meat texture is highly valued and, in general, good quality meat is perceived as tender, although other factors, such as cohesiveness, viscosity, elasticity, gumminess, chewiness, juiciness, brittleness and adhesiveness also determine texture. Color is also a valuable trait when deciding to buy the product and while consuming it (Gaya \& Ferraz, 2006). Juiciness is also important during meat consumption. Although these are not the only valuable traits, they are the determining factors when deciding to buy and continue to consume meat (Duarte et al., 2010). Therefore, meat traits that determine consumer market acceptance, i.e., tenderness, color and juiciness were evaluated. Tenderness is determined by shear force, color by lightness, redness, and yellowness, and juiciness by water holding capacity. Meat $\mathrm{pH}$ change after slaughter also greatly influences 
its tenderness, juiciness and color. These characteristics are all interrelated, and the speed at which meat $\mathrm{pH}$ decreases affects water holding capacity, tenderness and color. Fast pH drop causes quick post-mortem glycolysis, which may result in PSE (pale, soft and exudative) meat. On the other hand, when $\mathrm{pH}$ does not decrease post-mortem, meat can become dark, firm, and dry (DFD metat), indicating that little glucose was available to be converted into lactic acid (Ramos \& Gomide, 2007).

None of the variables included in the statistical model significantly affected $(p>0.05)$ the quality traits of tinamou breast meat (Table 4). The coefficients of determination varied between 18 and 34\%, indicating that other variables not included in the model may have been responsible for important changes of these traits. Shear force (Sf), redness ( $\left.a^{*}\right)$, and yellowness $\left(b^{*}\right)$ presented high coefficients of variation, of $51 \%, 51 \%$ and $62 \%$, respectively, which shows a wide dispersion of the measured values.

Table 4 - Summary of the analysis of variance of shear force (Sf), pH, water holding capacity (Whc), lightness $\left(L^{*}\right)$, redness $\left(a^{*}\right)$ and yellowness $\left(b^{*}\right)$ results of tinamou (Rhynchotus rufescens) breast meat.

\begin{tabular}{lccccccc}
\hline $\begin{array}{l}\text { Variation } \\
\text { source }\end{array}$ & GL & \multicolumn{7}{c}{ Mean square } & & & & \\
\hline \multicolumn{1}{c}{ Sf } & & $\mathrm{pH}$ & $\mathrm{Whc}$ & $\mathrm{L}^{*}$ & $\mathrm{a}^{*}$ & $\mathrm{~b}^{*}$ \\
\hline Treatment & 3 & 1341316.10 & 0.024 & 3.9 & 14.75 & 0.16 & 1.02 \\
Breast score & 2 & 157675.41 & 0.006 & 5.05 & 3.2 & 0.85 & 1.06 \\
Bln & 1 & 1122996.50 & 0.011 & 18 & 27.9 & 1.07 & 2.36 \\
Blw & 1 & 313367.50 & 0.008 & 0.37 & 23.7 & 0.37 & 5.97 \\
Bsw & 1 & 6015.40 & 0.00001 & 15.7 & 8.75 & 0.25 & 0.73 \\
Bw & 1 & 1437689.40 & 0.003 & 7 & 7.4 & 0.58 & 2.98 \\
Residual & 20 & 959559.30 & 0.0015 & 8.25 & 27.4 & 1.02 & 0.99 \\
\hline R $(\%)$ & & 24 & 22 & 24 & 23 & 18 & 34 \\
CV (\%) & & 51 & 2 & 4 & 11 & 51 & 62 \\
\hline
\end{tabular}

${ }^{*} p<0.10, G L=$ degrees of freedom, Bln = breast length, Blw = breast large width, $\mathrm{Bsw}=$ breast small width and $\mathrm{BW}=$ breast weight, $\mathrm{R}^{2}=$ coefficient of determination, $\mathrm{CV}=$ coefficient of variation.

Means and standard deviation values of shear force, $\mathrm{pH}$, water holding capacity, lightness, redness and yellowness were: $1.92 \pm 0.98 \mathrm{kgf} . \mathrm{cm}^{-2}, 6.07 \pm 0.12$; $70 \pm 0.53 \%, 48.30 \pm 0.96,1.96 \pm 1.01$ and $1.61 \pm 1.0$, respectively (Table 5 ).

Duarte et al. (2007) compared breast meat traits between tinamous and broilers and found that tinamou meat was slightly less acidic (pH 6.07 tinamou vs. 5.7 broiler), lightness was very similar (48.3 tinamou vs. 47.21 broiler), but it was more tender (1.92 vs. 4.64 kgf/ $\mathrm{cm}^{2}$ ) than broiler breast meat. Water holding capacity was slightly higher for tinamou meat compared with broiler meat (70\% and $67 \%$, respectively). Although broiler meat $a^{*}$ and $b^{*}$ values were slightly higher $\left(a^{*}=2.75\right.$ and $\left.b^{*}=4.26\right)$, both meats were within the standard range for poultry (Ramos \& Gomide, 2007).

Table 5 - Mean shear force (Sf), pH, Water holding capacity $(W h c)$, lightness $\left(L^{*}\right)$, redness $\left(a^{*}\right)$ and yellowness $\left(b^{*}\right)$ values of tinamou (Rhynchotus rufescens) breast meat.

\begin{tabular}{lcccccccc}
\hline & N & Sf kgf/cm² & pH & Whc \% & $L^{*}$ & $a^{*}$ & $b^{*}$ \\
\hline Mean & 30 & 1.92 & 6.07 & 70.00 & 48.3 & 1.96 & 1.61 \\
Deviation & 30 & 0.98 & 0.12 & 2.87 & 5.2 & 1.01 & 1.0 \\
\hline
\end{tabular}

Oba et al. (2007), studying meat traits of broilers supplemented with chromium and submitted to different room temperatures, reported higher water holding capacity $(73 \%)$, shear force $\left(2.33 \mathrm{kgf} . \mathrm{cm}^{-2}\right)$, as well as $a^{*}$ (3.01) and $b *$ (6.6) values compared with the present study. The results showed that redness is higher than yellowness in tinamou meat, with an $a * / b *$ ratio of 1.22 , indicating the presence of heme pigments, good water holding capacity, and tenderness, which leads to the conclusion that tinamou meat is similar to broiler meat, only slightly less acidic and more tender.

Means and standard deviation of the parameters moisture, ash, crude protein, fat, and cholesterol contents were, respectively, $72.35 \pm 0.16 \%$, $1.12 \pm 0.06 \%, 25.53 \pm 0.50 \%, 0.17 \pm 0.01 \%$, and $18.87 \pm 2.76 \mathrm{mg} / 10 \mathrm{~g}$. Garcia et al. (2005), studying chicken meat traits, reported the following means for the same parameters $72.32 \%, 1.16 \%, 23.57 \%$, $1.17 \%$, and $20.01 \mathrm{mg} / 10 \mathrm{~g}$. It is observed, therefore, that tinamou meat is very similar to chicken meat, but with higher protein content and lower fat and cholesterol levels.

In conclusion, the present study confirms that tinamou carcass yield is very similar to that of broilers. Tinamou meat presented lightness values between 45 and 50, and similar redness and yellowness values relative to chicken meat, that is, it is neither dark nor pale. Also, water holding capacity is similar in both meats, as well as nutritional values. However, tinamou meat is more tender, less acidic, contains higher protein levels, and less calories and lower cholesterol level compared with chicken meat. 


\section{ACKNOWLEDGEMENTS}

We are thankful to CNPq (Conselho Nacional de Desenvolvimento Científico e Tecnológico) for the grants given to the authors.

\section{REFERENCES}

Aggrey SE, Nichols CR, Cheng M. The partridge tinamou for commercial meat production: A preliminary evaluation. Proceedings of the 19th World's Poultry Congress; 1992; Amsterdam. Holland. p. 360

Association of Official Analytical Chemists. Official methods of analysis. 18th ed. Arlington; 2004. v.2.

Bragnolo N, Rodrigues-Amaya DB. Avaliação comparativa de três métodos para determinação colesterol em gema de ovo. Arquivo de Biologia Tecnológica 1993;36:237-251

Bruneli FAT, Tholon P, Isaac FL, Damasceno, PR, Tonhati, H, Queiroz SA. Caracterização da reprodução de perdizes (Rhynchotus rufescens) em cativeiro. Ars veterinária 2005;21(2)272-280.

Cancherini LC, Duarte KF, Junqueira OM, Filardi RS, Laurentiz AC, Araújo LF. Desempenho e rendimento de carcaça de frangos de corte alimentados com dietas contendo subprodutos do arroz formuladas com base nos conceitos de proteína bruta e ideal. Revista Brasileira de Zootecnia 2008; 37(4):616-623.

Duarte KF, Junqueira OM, Filardi RS, Laurentiz AC, Souza HBA, Oliveira, TMFS. Efeito dos níveis de energia e programas de alimentação sobre a qualidade de carcaça e desempenho de frangos de corte abatidos tardiamente. Acta Scientiarum Animal Science 2007;29(1):39-47.

Duarte KF, Junqueira OM, Borges LL. Qualidade e segurança na produção de carne de aves [cited 2010 fev 25].Available from: http://pt.engormix. com/MA-avicultura/industria-carne/artigos/qualidade-segurancaproducao-carne-t246/471-p0.htm.

Garcia RG, Mendes AA, Costa C, Paz ICLA, Takahashi SE, Pelícia KP, Komiyama CM, Quinteiro RR. (2005) Desempenho e qualidade da carne de frangos de corte, alimentado com diferentes níveis de sorgo em substituição ao milho. Arquivo Brasileiro de Medicina Veterinária e Zootecnia 2005;57(5): 634-643.
Gaya LG, Ferraz JBS. Aspectos genético-quantitativos da qualidade da carne em frangos. Ciência Rural 2006;36(1):349-356.

Hamn R. Biochemistry of meat hydratation. Advances in Food Research 1960;10:335-443

Denadai JC, Mendes AA, Garcia RG, Almeida ICL, Moreira J, Takita TS, Pavan AC, Garcia EA. Efeito na duração do período de jejum pré-abate sobre o rendimento de carcaça e a qualidade da carne do peito de frangos de corte. Revista Brasileira de Ciência Avícola 2002:4(2):101109.

Kermode D. The production of non-traditional poultry in British Columbia and the introduction of a new poultry species: Partridge Tinamou [dissertation]. Vancouver (BC): University of British Columbia; 1997[cited 2010 April]. Available from: from:https://circle.ubc.ca/ bitstream/handle/2429/5960/ubc_1997-0249.pdf.

Lyon CE, Lyon BG, Dickens JA. Effects of carcass stimulation, deboning time, and marination on color and texture of broiler breast meat. Journal of Applied Poultry Research 1998;7(1):53-60.

Moro MEG, Arik J, Souza PA, Souza HBA, Moraes VMB, Vargas FC. Rendimento de carcaça e composição química da carne da perdiz nativa (Rhynchotus rufescens). Ciência Rural 2006;36(1):258-262.

Oba A, Souza PA, Souza HBA, Leonel FR, Pelicano ERL, Zeoula NMB, Bolelli IC. (2007) Qualidade da carne de frangos de corte submetidos a dietas suplementadas com crômio, criados em diferentes temperaturas ambientais. Acta Scientiarum Animal Science 2007;29(2):143-149.

Queiroz SA, Cooper RG. Gender-based differences in stride and limb dimensions between healthy red-wing tinamou (Rhynchotus rufescens) Temminck, 1815. Turkish Journal of Zoology 2011;35(1):103-108.

Ramos EM, Gomide LAM. (2007) A cor da carne. In: Ramos EM, Gomide LAM, editor. Avaliação da qualidade de carnes, fundamentos e metodologias. Viçosa: Editora UFV; 2007. p.242-321.

Sick H. Ordem tinamiformes. In: Sick H, editor. Ornitologia Brasileira. Rio de Janeiro: Nova Fronteira; 1997. p.153-167.

Tholon P, Queiroz SA. Models for the analysis of growth curves for rearing tinamou (Rhynchotus rufescens) in captivity. Brazilian Journal of Poultry Science 2007;9(1):23-31

Weeks SE. The behavior of de red-winged tinamou, Rhynchotus rufescens. Zoologica 1973;58(1):13-40. 